\title{
Seasonal succession in zooplankton feeding traits reveals trophic trait coupling
}

\author{
Kenitz, Kasia; Visser, Andre; Mariani, Patrizio; Andersen, Ken Haste
}

Published in:

Limnology and Oceanography

Link to article, DOI:

10.1002/Ino.10494

Publication date:

2017

Document Version

Publisher's PDF, also known as Version of record

Link back to DTU Orbit

Citation (APA):

Kenitz, K., Visser, A., Mariani, P., \& Andersen, K. H. (2017). Seasonal succession in zooplankton feeding traits reveals trophic trait coupling. Limnology and Oceanography, 62(3), 1184-1197. https://doi.org/10.1002/lno.10494

\section{General rights}

Copyright and moral rights for the publications made accessible in the public portal are retained by the authors and/or other copyright owners and it is a condition of accessing publications that users recognise and abide by the legal requirements associated with these rights.

- Users may download and print one copy of any publication from the public portal for the purpose of private study or research.

- You may not further distribute the material or use it for any profit-making activity or commercial gain

- You may freely distribute the URL identifying the publication in the public portal 


\title{
Seasonal succession in zooplankton feeding traits reveals trophic trait coupling
}

\author{
Kasia M. Kenitz, ${ }^{*}$ André W. Visser, Patrizio Mariani, Ken H. Andersen
}

VKR Centre for Ocean Life, National Institute of Aquatic Resources, Technical University of Denmark, Charlottenlund, Denmark

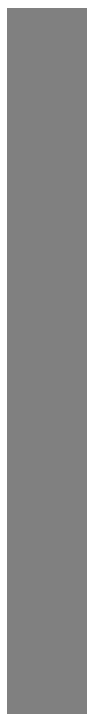

\begin{abstract}
The seasonal forcing of pelagic communities invokes a succession of the dominant phytoplankton and zooplankton species. Here, we characterize the seasonal succession of the plankton traits and their interactions using observations and model simulations of the plankton community in the western English Channel. We focus on activity traits that characterize the defensive and feeding abilities of zooplankton and distinguish between low risk, low return ambush feeders and high risk, high return feeding-current feeders. While the phytoplankton succession depends on traits related to nutrient acquisition and photosynthesis, it also depends on grazing which couples feeding and motility traits across trophic guilds. Despite interannual variations in the species dominating the protist plankton community, the seasonal trait distribution reveals robust and repeatable seasonal patterns, changing between non-motile cells flourishing in spring and motile community dominating during summer. The zooplankton community is dominated by active feeding-current feeders with peak biomass in the late spring declining during summer. The model reveals how zooplankton grazing reinforces protist plankton seasonal succession and shows how the physical environment controls the vertical structure of plankton communities, where ambush feeders exhibit a preference for greater depths during summer. We characterize the seasonal succession as trophic trait coupling and conjecture that this coupling leads to a trophic trait cascade where successive trophic levels alternate in their expression of activity traits further up in the food chain.
\end{abstract}

The succession of species in plankton communities reflects a shifting balance between resource availability and predation, and the constantly changing trophic arrangements these promote (Behrenfeld and Boss 2014; Acevedo-Trejos et al. 2015). For phytoplankton communities, for instance, early colonists are favored by the ability to assimilate resources rapidly while those with efficient resource economics have a competitive advantage later in the season (Tilman 1982; Edwards et al. 2013). The description of the succession in terms of functional traits and their associated trade-offs is a powerful way of simplifying the complex changes in the species composition. A trait is a characteristic feature of an organism that affects its fitness through mediating growth, reproduction or survival (Litchman and Klausmeier 2008; Litchman et al. 2013). Physiological traits and trade-offs have been widely quantified for aquatic microbes (Litchman and Klausmeier 2008; Litchman et al. 2010), for example, light dependency (Falkowski and

*Correspondence: kken@aqua.dtu.dk

Additional Supporting Information may be found in the online version of this article.
Owens 1980; Bidigare et al. 1990; Hickman et al. 2010), nutrient acquisition and maximum growth (Edwards et al. 2012), and optimum temperature for growth (Eppley 1972; Thomas et al. 2012), and they have been used to predict spatial and temporal variations in trait distributions (Follows et al. 2007; Hickman et al. 2010; Monteiro et al. 2010).

While the seasonal trait succession of phytoplankton has been described earlier (Edwards et al. 2013) little is known about the succession of the zooplankton traits and its implications for other trophic levels. This paucity is probably a result of more complex morphologies and behaviors of zooplankton. The seasonal variation in zooplankton abundance has been well documented, with implications for the structuring of the protist community through grazing (Evans and Parslow 1985; Evans 1988; Behrenfeld and Boss 2014). The question we seek to address here is whether there is a systematic seasonal succession in the traits expressed in the zooplankton community and if so, how are these coupled to the congruent succession of traits of the protist plankton.

Zooplankton are characterized by physiological and behavioral traits that affect their ecological function and influence their interactions with other trophic levels (Litchman et al. 
2013). Here, we focus on zooplankton feeding as it is directly linked to the protist plankton community. In particular, the feeding mode has been shown to be a key trait, trading off defensive and feeding capabilities (Kiørboe 2008a,2011). Feeding can be divided into passive and active modes (Kiørboe 2011). Active feeders search for food by either swimming or generating a feeding current (or both) while passive feeding characterizes non-motile, ambush feeders that wait for motile prey to pass within their sensory reach. These different feeding modes incur different costs and risks as well as targeting different prey types. Active feeding is in general more effective than passive feeding due to greater volume of water scanned, but incurs a greater predation risk and is energetically more costly (Eiane and Ohman 2004; Kiørboe 2011). In contrast, passive feeding has lower costs and risks, but relies on the motility of the prey to bring about encounters with food, a process that can be enhanced by small scale turbulence (Saiz and Kiørboe 1995). Active feeding mainly targets non-motile prey due to the ability of many motile flagellates to escape in response to predator-induced fluid signals (Jakobsen 2002; Kiørboe 2011). The environmental selection for feeding mode therefore depends on a combination of predation risk, turbulence, prey abundance and type (motile vs. non-motile), and is expected to vary on temporal and spatial scales. Conversely, the grazing pressure on the motile and non-motile fractions of the protist community will depend on which zooplankton feeding mode is dominating (Mariani and Visser 2010). Thus, changes in the trait composition of the zooplankton community directly influences the protist community and vice versa.

To describe and understand the seasonal succession in motility and feeding traits of plankton communities, we apply a combination of observations and numerical simulations. We show that while zooplankton species composition differs between years, feeding trait succession consistently follows repeated cycles. A simple trait-based model provides insight into the mechanisms driving the observed trait succession and the seasonal shifts in the copepod community structure.

\section{Methods}

We use observational time-series data on plankton composition from station L4 in the western English Channel to investigate seasonal patterns and distribution of the zooplankton feeding, and protist plankton motility traits. Moreover, a simple community model of plankton interactions is implemented for the English Channel to provide insight into potential drivers shaping the plankton succession. In this, we focus on a mechanistic description of the coupling between feeding and motility traits. The purpose of model implementation is not to replicate the observational data, but to investigate whether interactions between copepods and the protist plankton community could be a potential driver of trait distribution patterns observed in nature.

\section{Plankton time series from the L4 station, English Channel}

The time series of phytozooplankton and microzooplankton biomass and mesozooplankton abundance were provided by the Western Channel Observatory. The sampling site is the coastal station $\mathrm{L} 4\left(4^{\circ} \mathrm{W} 50^{\circ} \mathrm{N}\right)$, located within $40 \mathrm{~km}$ off Plymouth, UK. The station is $50 \mathrm{~m}$ deep and subjected to a strong advective influence, with the variability in nutrient concentrations in the top $20 \mathrm{~m}$ linked to the estuary of river Tamar (Smyth et al. 2010).

Plankton data were collected at quasi-weekly intervals for the period from October 1992 to December 2013 for phytozooplankton and microzooplankton, and from March 1988 to December 2014 for mesozooplankton. The data were averaged to a monthly resolution in order to account for the non-homogenous sampling effort. Phytoplankton and microzooplankton samples were collected from $10 \mathrm{~m}$ depth as described by Widdicombe et al. (2010). Recorded cell volume was converted to carbon biomass using carbon to volume relationship from Menden-Deuer and Lessard (2000). Mesozooplankton samples were collected by vertical hauls with a $200-\mu \mathrm{m}$ mesh size net, from the sea floor (approx. $55 \mathrm{~m}$.) to the surface. The sampling mesh size likely underestimates the biomass of small individuals, which is especially relevant for the representation of the ambush-feeding community. However, assuming consistent undersampling, the seasonal patterns in the biomass distribution should be reasonably well represented.

\section{Classification of motility traits}

Phytoplankton and microzooplankton community is classified into two distinctive groups based on their motility traits. Non-motile group includes diatoms and coccolithophores. Motile community is composed of dinoflagellates, ciliates and zooflagellates.

\section{Copepod species selection and transfer to carbon biomass}

The 12 most abundant copepod species recorded at L4 are included in the analysis (Table 1). These species dominate the copepod biomass and are sufficiently abundant to capture the seasonal patterns of variability. Individual species are assigned an average prosome length for an adult, and the number of individuals was converted to carbon biomass using the size relationship derived by Hopcroft et al. (1998).

In 2009, a consistent classification was initiated to separate counts of adults and juveniles (copepodite stages CI-V). In order to avoid an overestimation of the species biomass in the earlier years when the juveniles were not counted independently, a seasonal pattern of juvenile abundance is identified based on the 2009-2014 records. An average monthly ratio of juveniles to adults is then used as a scaling factor to estimate the proportion of juveniles in years prior 
Table 1. Prosome length and calculated carbon content for the copepod species considered in the study. Prosome length is given for an average adult, A, and for early copepodite stages, $\mathrm{Cl}-\mathrm{V}$. Carbon content is calculated from a logarithmic relation with the length of each individual given by Hopcroft et al. (1998).

\begin{tabular}{|c|c|c|c|}
\hline Copepod species & Stage & $\begin{array}{c}\text { Prosome } \\
\text { length } \\
(\mu \mathrm{m})\end{array}$ & $\begin{array}{l}\text { Carbon content } \\
\left(\mu \mathrm{g} \mathrm{C} \text { ind }^{-1}\right)\end{array}$ \\
\hline \multicolumn{4}{|l|}{ Active feeders } \\
\hline \multirow[t]{2}{*}{ Acartia clausi } & $A$ & $900^{1,2,3,4}$ & 6.23 \\
\hline & $\mathrm{Cl}-\mathrm{V}$ & $520^{1}$ & 1.14 \\
\hline \multirow[t]{2}{*}{ Calanus helgolandicus } & $A$ & $2600^{1,3,4,5}$ & 169.92 \\
\hline & $\mathrm{Cl}-\mathrm{V}$ & $1400^{1,5}$ & 31.16 \\
\hline \multirow[t]{2}{*}{ Centropages typicus } & $A$ & $1200^{1,3}$ & 20.43 \\
\hline & $\mathrm{Cl}-\mathrm{V}$ & $600^{1}$ & 3.06 \\
\hline Clausocalanus spp. & A & $700^{3}$ & 5.16 \\
\hline Ctenocalanus vanus & $A$ & $700^{3,4}$ & 4.66 \\
\hline Metridia lucens & $A$ & $1300^{1}$ & 25.44 \\
\hline Oncaea spp. & $A$ & $400^{1,3,4}$ & 1.10 \\
\hline Paracalanus parvus & $A$ & $700^{1,3,4}$ & 5.16 \\
\hline Pseudocalanus elongatus & A & $820^{1,3,4}$ & 7.20 \\
\hline \multirow[t]{2}{*}{ Temora longicornis } & $A$ & $830^{1,3,4}$ & 7.44 \\
\hline & $\mathrm{Cl}-\mathrm{V}$ & $450^{1}$ & 1.39 \\
\hline $\begin{array}{c}\text { Clauso/Cteno/Para/ } \\
\text { Pseudocalanus }\end{array}$ & $\mathrm{Cl}-\mathrm{V}$ & $500^{1}$ & 1.73 \\
\hline \multicolumn{4}{|l|}{ Passive feeders } \\
\hline Corycaeus spp. & $A$ & $540^{3}$ & 3.02 \\
\hline Oithona spp. & $A$ & $500^{1,3,4}$ & 2.23 \\
\hline
\end{tabular}

Sources: ${ }^{1}$ Conway $(2012 a),{ }^{2}$ Berggreen et al. (1988), ${ }^{3}$ Conway $(2012 b)$, ${ }^{4}$ Rose (1933), ${ }^{5}$ Bottrell and Robins (1984).

to 2009. Carbon content for juveniles is derived based on the average size for stages CI-IV (see Table 1).

The interannual variability in the biomass of individual species (and feeding groups discussed in the following section) is captured by the variation index, $c_{\mathrm{v}}$. The variation index is a non-parametric measure analogous to the coefficient of variation, and is defined as a ratio of inter-quartile range (IQR) to the median, $c_{\mathrm{v}}=\mathrm{IQR} /$ median.

\section{Classification of feeding traits}

Copepods are grouped depending on their preferred feeding strategy for capturing prey: active feeding (i.e., cruising or feeding-current) and passive feeding (i.e., ambush). We only consider adult and juvenile copepods. Copepod nauplii are too small to be accurately sampled and the existent data on nauplii abundance lacks species-specific classification. Calanoid copepods are classified as active feeders, while passive feeders include cyclopoid and poecilostomatoid copepods that are represented by Oithona and Corycaeus spp., respectively (Benedetti et al. 2015; Table 1). Species such as Acartia and Centropages perform a mixed feeding strategy with the ability to switch between ambush and feeding-current feeding (Saiz and Kiørboe 1995; Kiørboe et al. 1996; Benedetti et al. 2015). Here, these species are classified as active feeders due to their adaptive feeding ability. Oncaea spp. are classified as active feeders due to their active swimming behavior (Seuront et al. 2004) and complex feeding regime that ranges from detritivory to omnivory (Benedetti et al. 2015), including ingestion of both diatoms and dinoflagellates, and larger zooplankton (Turner et al. 1984; Go et al. 1998).

The monthly biomass of each feeding group $\left(B_{t}\right)$ is normalized by the total annual biomass of the feeding group $\left(\sum_{\mathrm{T}} B_{\mathrm{T}}\right)$ to obtain seasonal distribution $(D)$ :

$$
D_{t}=\frac{B_{t}}{\sum_{\mathrm{T}} B_{\mathrm{T}}}, t=1, \ldots, 12
$$

The implementation of normalized biomass aims to clearly visualize the relative variability in the seasonal patterns between feeding groups, and to compensate for undersampling of the ambush-feeding community.

\section{Plankton community model}

The biological model simulates interactions between passive (ambush) and active (feeding-current feeding) zooplankton and their corresponding prey types in a one-dimensional water column (Fig. 1) and its physical setting is parameterized to conform to the western English Channel. The trait-based representation of the zooplankton community follows Mariani et al. (2013), extended to include the seasonal and vertical variability in nutrient concentration. Planktonic interactions thus now include prey competition for nutrients and the functional response of zooplankton grazing. The biological model is coupled to the physical environment through the General Ocean Turbulence Model (GOTM; Burchard et al. 2006). The model is set up for the L4 station, with the physical environment driven by tidal forcing and local meteorology to provide seasonally varying vertical profiles of light ( $I$ $\left.\left[\mathrm{Wm}^{-2}\right]\right)$, dissipation rate $\left(\epsilon\left[\mathrm{m}^{3} \mathrm{~s}^{-2}\right]\right)$, and vertical diffusivity $\left(k_{z}\left[\mathrm{~m}^{2} \mathrm{~s}^{-1}\right]\right)$. More information on the physical properties at the sampling site and the set-up of the physical model is provided in the Supporting Information S1.

Two types of protist prey are considered in the model: motile $\left(P_{\mathrm{m}}\left[\mathrm{mmol} \mathrm{N} \mathrm{m}{ }^{-3}\right]\right)$ and non-motile $\left(P_{\mathrm{n}}[\mathrm{mmol} \mathrm{N}\right.$ $\left.\left.\mathrm{m}^{-3}\right]\right)$. The model implements a single macronutrient $(N$ $\left[\mathrm{mmol} \mathrm{N} \mathrm{m}^{-3}\right]$ ) dynamics, which allows for the vertical and seasonal variation in prey abundance to be bottom-up as well as top-down controlled. In this modelling framework, the motile prey community includes both autotrophic and heterotrophic aspects of the protist plankton community. We assume an efficient and instantaneous nutrient transfer due to a tight coupling between those two populations (Landry et al. 2000; Strom et al. 2007). Consequently, we consider the motile community as an integrated group, whose overall growth is determined by light, nutrients, and grazing by mesozooplankton. While this approach allows us to examine the succession of the motility 


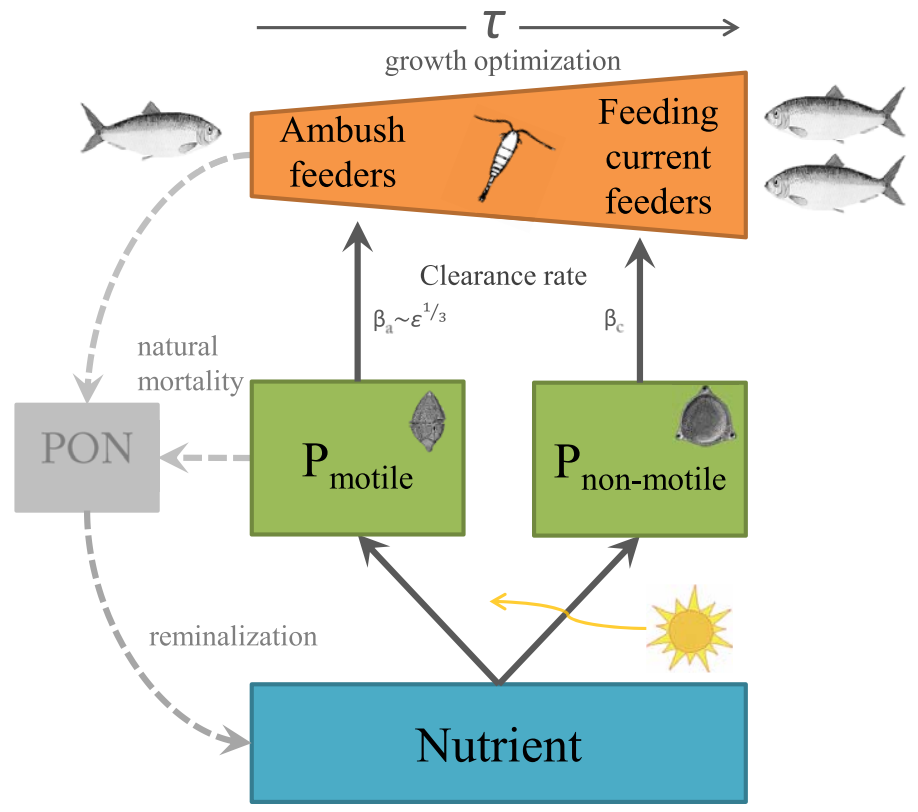

Fig. 1. Schematic illustration of interactions within the biological model.

traits of protists, an assessment of the community structure remains unresolved.

Nitrogen is distributed through the water column through vertical turbulent diffusion $(\Delta)$ and supplied through remineralization of particulate organic matter $\left(N_{\mathrm{POM}}\right)$ at a rate $k_{\mathrm{POM}}$. The nutrient loss occurs during protist growth controlled by the growth rates $\mu_{P_{\mathrm{m}}}$ and $\mu_{P_{\mathrm{n}}}$ for motile and non-motile protists respectively:

$$
\frac{\partial N}{\partial t}=-\Delta N-\mu_{P_{\mathrm{m}}} P_{\mathrm{m}}-\mu_{P_{\mathrm{n}}} P_{\mathrm{n}}+k_{\mathrm{POM}} N_{\mathrm{POM}}
$$

The vertical diffusion is represented as $\Delta=\frac{\partial}{\partial z} k_{z} \frac{\partial}{\partial z}$, where $z$ is the depth and $k_{z}$ is the vertical diffusivity.

The gross growth rate for each prey type $\left(\mu_{P_{\mathrm{m}}}\right.$ or $\left.\mu_{P_{\mathrm{n}}}\right)$ is controlled by the availability of light $(I)$ and nitrogen concentration $(N)$. The maximum growth rate $\left(\mu_{\max }\right)$ of each prey type is then scaled by non-dimensional factors imposing nutrient and light limitation (following formulation of Follows et al. 2007):

$$
\mu=\mu_{\max } \frac{A_{N} N}{\mu_{\max }+A_{N} N} \frac{A_{I} I}{\mu_{\max }+A_{I} I},
$$

where $A_{N}$ and $A_{I}$ are affinities for nutrient and light, respectively.

Non-motile protist plankton are better nutrient competitors, and are assigned higher $\mu_{\max }$ and $A_{N}$ (Edwards et al. 2012). In order to account for the benefit of motility, a constant sinking speed $\left(w_{P_{\mathrm{n}}}\right)$ is imposed on the non-motile cells only (last term in Eq. 4). Model parameters and values are listed in Table 2.
Protist plankton biomass is determined through diffusive transport $(\Delta)$, the bottom-up control on growth, non-grazing mortality $\left(m_{P}\right)$, top-down control from zooplankton $(Z$ $\left[\mathrm{mmol} \mathrm{N} \mathrm{m}^{-3}\right]$ ) grazing, and through sinking (only for nonmotile cells):

$$
\begin{gathered}
\frac{\partial P_{\mathrm{n}}}{\partial t}=-\Delta P_{\mathrm{n}}+\left(\mu_{P_{\mathrm{n}}}-m_{P}\right) P_{\mathrm{n}}-\tau \frac{g_{\max } \beta_{\mathrm{c}} P_{\mathrm{n}}}{g_{\max }+\beta_{\mathrm{c}} P_{\mathrm{n}}} Z-\frac{\partial\left(w_{P_{\mathrm{n}}} P_{\mathrm{n}}\right)}{\partial z} \\
\frac{\partial P_{\mathrm{m}}}{\partial t}=-\Delta P_{\mathrm{m}}+\left(\mu_{P_{\mathrm{m}}}-m_{P}\right) P_{\mathrm{m}}-(1-\tau) \frac{g_{\max } \beta_{\mathrm{a}} P_{\mathrm{m}}}{g_{\max }+\beta_{\mathrm{a}} P_{\mathrm{m}}} Z
\end{gathered}
$$

Variable $\tau$ represents adaptive feeding strategy and denotes the proportion of zooplankton performing active feeding. Parameters $\beta_{\mathrm{a}}$ and $\beta_{\mathrm{c}}$ represent clearance rates $\left[\mathrm{m}^{3} \mathrm{~s}^{-1}\right]$ for ambush (passive) and feeding-current feeding (active) strategies. The maximum grazing rate $\left(g_{\max }\right)$ remains constant irrespective of the feeding behavior. Calculations of $\tau, \beta_{\mathrm{a}}$, and $\beta_{\mathrm{c}}$ are discussed in more detail later in this section.

Zooplankton is modelled with a single state variable $(Z)$ that adaptively varies between active and passive (feedingcurrent and ambush) feeding. These feeding behaviors are regulated by the continuous variable $\tau$ that changes dynamically to maximize the instantaneous population growth. We note that although some copepod species, such as Acartia and Centropages, exhibit adaptive behavior (Kiørboe et al. 1996; Benedetti et al. 2015), the majority of copepod species considered in the analysis of the observational data do not. Nonetheless, we use this simplified formulation with the adaptive behavior of a single trait since alternative formulations show essentially similar dynamics (Abrams and Matsuda 2004).

Zooplankton growth $(g(\tau))$ is controlled by the consumption of prey biomass with assimilation efficiency, $\gamma$, and mortality:

$$
\begin{aligned}
\frac{\partial Z}{\partial t} & =-\Delta Z+g(\tau) Z= \\
& -\Delta Z+\gamma\left((1-\tau) \frac{g_{\max } \beta_{\mathrm{a}} P_{\mathrm{m}}}{g_{\max }+\beta_{\mathrm{a}} P_{\mathrm{m}}}+\tau \frac{g_{\max } \beta_{\mathrm{c}} P_{\mathrm{n}}}{g_{\max }+\beta_{\mathrm{c}} P_{\mathrm{n}}}\right) Z-\left(m_{Z}+\tau p\right) Z
\end{aligned}
$$

The efficiency of prey capture and the risk of predation are key processes that influence the feeding mode that optimizes the survival of zooplankton in the biological model. The ability of zooplankton to switch aims to illustrate the optimal feeding strategy that an individual needs to adopt in order to maximize population growth. The timing of switching from one to another feeding strategy will not only reveal the behavioral pattern of copepods that are able to adopt both feeding strategies (such as Acartia and Centropages spp.), but also illustrates which feeding strategy is optimal, that is when species that exhibit a particular feeding strategy will benefit most. Zooplankton switch their feeding behavior subject to variable $\tau$, which changes proportionally to the fitness gradient to optimize population growth: 
Table 2. Biological model parameters. Sources of parameter estimates are indicated in the footnote.

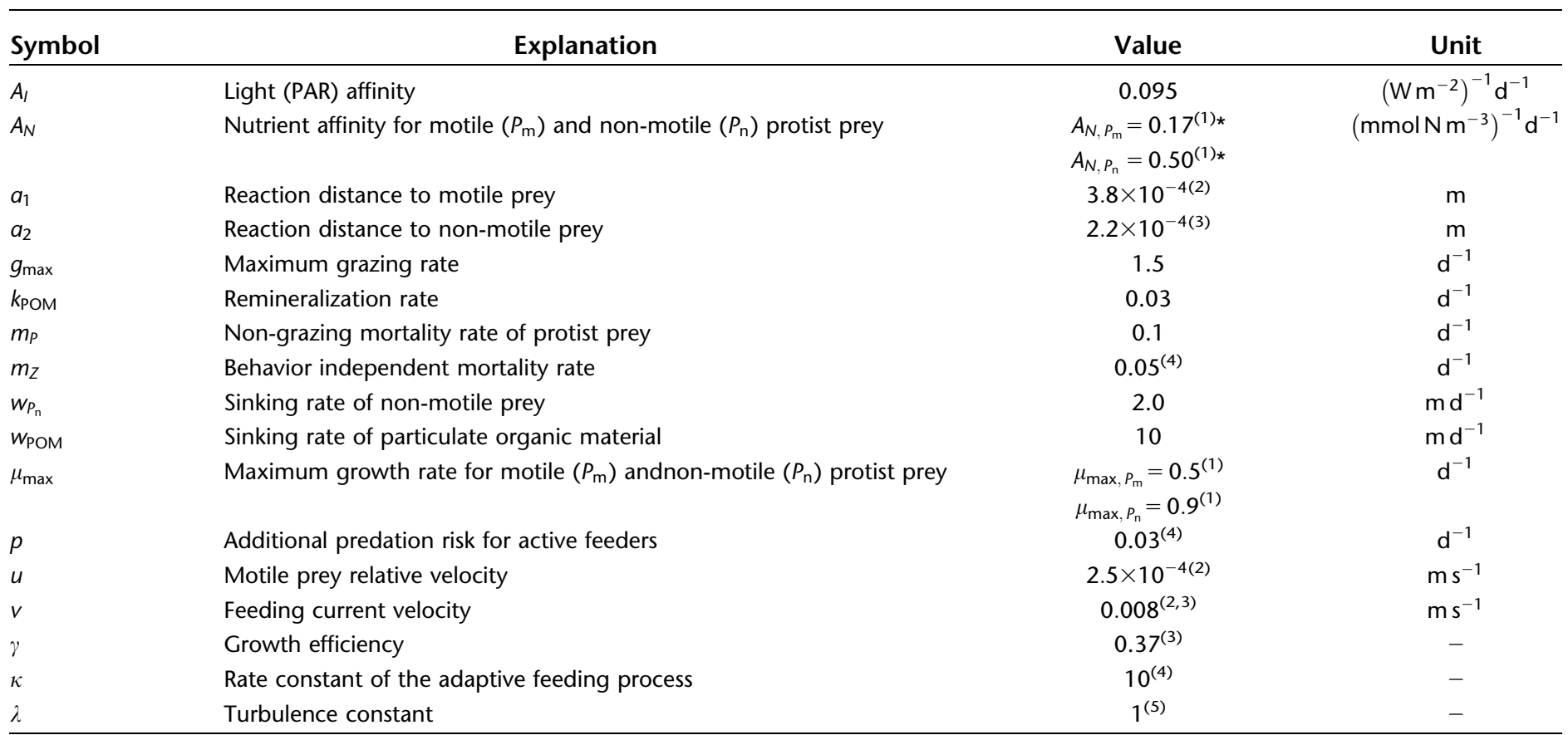

${ }^{(1)}$ Edwards et al. (2012), ${ }^{(2)}$ Saiz and Kiørboe (1995), ${ }^{(3)}$ Kiørboe (2008b), ${ }^{(4)}$ Mariani et al. (2013), (5)Delichatsios and Probstein (1975).

* Calculated as a ratio of maximum growth rate to half-saturation coefficient.

$$
\frac{\partial \tau}{\partial t}=\kappa \frac{\partial g}{\partial \tau}
$$

The behavioral parameter $\tau$ denotes the proportion of the zooplankton community that exhibits the feeding-current feeding strategy: the numerical integration of $\frac{\partial \tau}{\partial t}$ is conducted with imposed upper and lower limits so $0 \leq \tau \leq 1$ (Abrams et al. 1993; Mariani et al. 2013). The constant $\kappa$ determines the speed of the behavioral change. Change in the feeding behavior in the model promotes a shift in the type of consumed prey, from motile prey ingested by ambushers to non-motile prey consumed by feedingcurrent feeders. The costs and benefits of a feeding strategy are embodied in trade-offs with mortality and encounter rate. Mortality rate, $m_{Z}+\tau p$, depends on feeding strategy, with feedingcurrent feeders experiencing an additional predatory risk $(p)$ due to increased hydromechanical conspicuousness.

The encounter rate with prey increases in moderately turbulent environments for ambush feeders (Saiz and Kiørboe 1995) and the clearance rate hence depends on the turbulent dissipation rate $(\epsilon)$ :

$$
\beta_{\mathrm{a}}=\pi a_{1}^{2}\left(\lambda\left(\epsilon a_{1}\right)^{1 / 3}+u\right)
$$

where $a_{1}$ is a reaction distance to motile prey, $u$ is the velocity difference between predator and its prey, and $\lambda$ is Richardson's constant (Richardson 1926; Delichatsios and Probstein 1975).
Turbulence has little effect on the efficiency of feedingcurrent feeding strategy (Saiz and Kiørboe 1995), and the clearance rate for feeding-current feeders is determined by:

$$
\beta_{\mathrm{c}}=\pi a_{2}^{2} v
$$

and depends only on the velocity of the generated current (v) and reaction distance to non-motile prey $\left(a_{2}\right)$.

The particulate nitrogen in detritus $\left(N_{\mathrm{POM}}\right)$ is supplied by decomposing protist plankton and predated zooplankton, and is lost through remineralization at rate $k_{\mathrm{POM}}$ and sinking at speed $w_{\text {POM }}$. Nutrients bounded in the biomass of predated zooplankton $\left(\left(m_{Z}+\tau p\right) Z\right)$ enter the detrital pool, accounting for the carbon transfer to higher trophic levels that eventually re-enters the organic nutrient pool, and complete the nutrient circulation in the model. The dynamics of $N_{\text {POM }}$ are described as:

$$
\begin{aligned}
\frac{\partial N_{\mathrm{POM}}}{\partial t}= & -\Delta N_{\mathrm{POM}}+m_{P}\left(P_{\mathrm{n}}+P_{\mathrm{m}}\right)+\left(m_{Z}+\tau p\right) Z-k_{\mathrm{POM}} N_{\mathrm{POM}} \\
& -\frac{\partial\left(w_{\mathrm{POM}} N_{\mathrm{POM}}\right)}{\partial z}
\end{aligned}
$$

Model sensitivity analysis is assessed by computing 1000 Monte Carlo simulations. The focal parameters include parameters that control the net growth $\left(A_{I}, A_{N}, \mu_{\max }, m_{P}\right)$ and sinking $\left(w_{P_{\mathrm{n}}}\right)$ of protist prey, and feeding $\left(g_{\max }, a_{1}, a_{2}, u, v, \lambda\right)$ and mortality $\left(m_{Z}, p\right)$ of zooplankton 


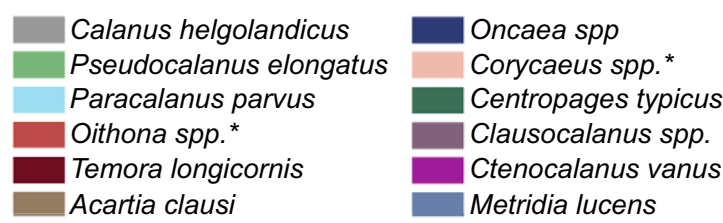

a)

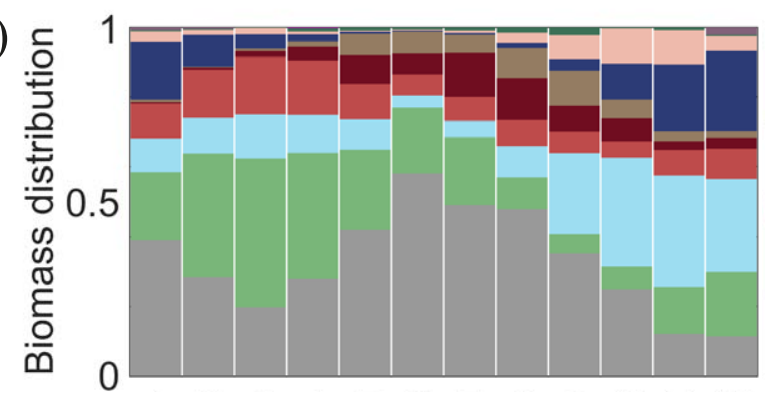

b)

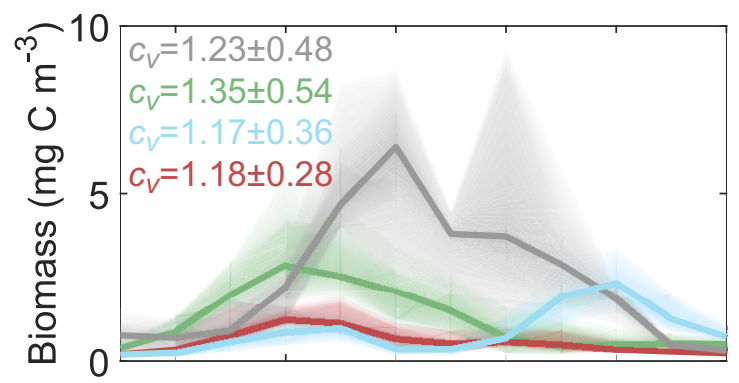

c)

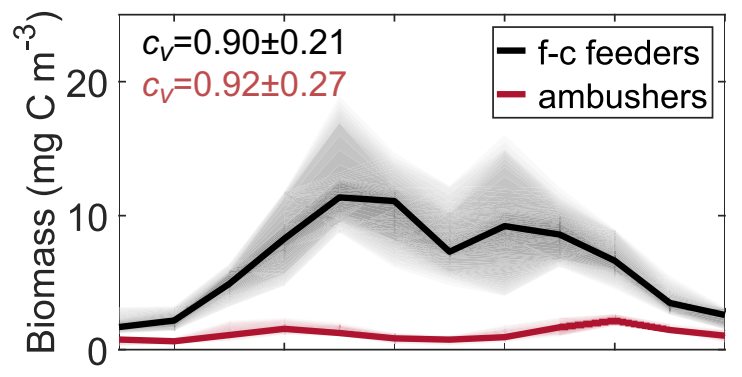

d)

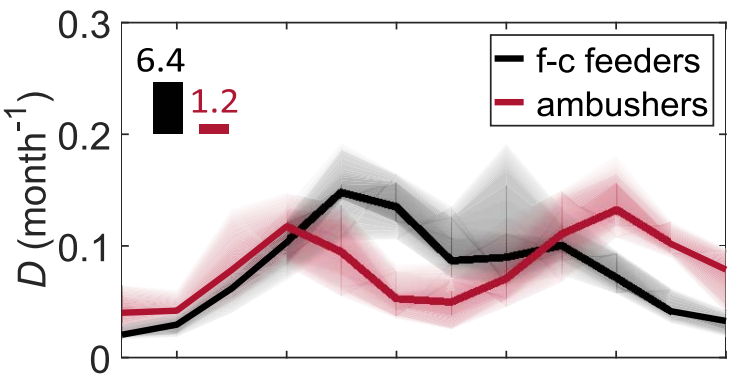

e)

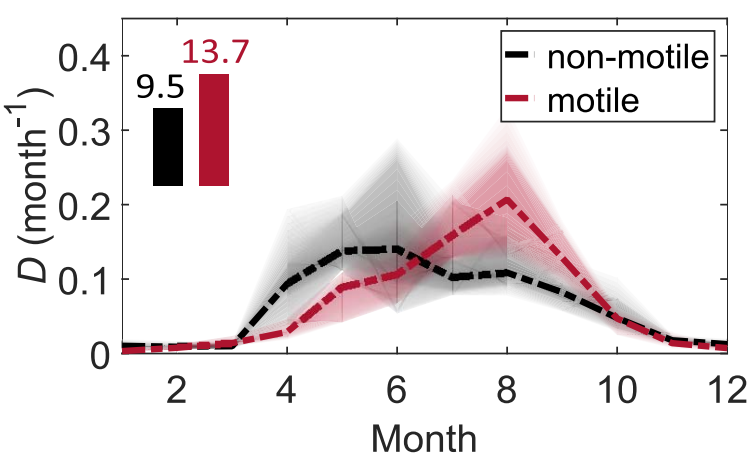

(more details in Supporting Information S2). Each parameter is varied individually within the range $\pm 30 \%$ of its base value indicated in Table 2.

The model is initiated with $N=6, P_{\mathrm{n}}=P_{\mathrm{m}}=Z=0.1, N_{\mathrm{POM}}=0$ mmol $\mathrm{N} \mathrm{m}^{-3}$ and $\tau=0.5$. The results are illustrated for year 5 of the simulation, after the model has stabilized and begun to produce a repeatable annual pattern. For figures illustrating plankton biomass, nitrogen units $\left[\mathrm{mmol} \mathrm{N} \mathrm{m}^{-3}\right]$ are converted to carbon biomass $\left[\mathrm{mg} \mathrm{C} \mathrm{m}^{-3}\right.$ ] assuming a molar $\mathrm{C}: \mathrm{N}$ ratio $=6.6: 1$ (Redfield 1958).

\section{Results}

Observations

The protist motility traits exhibit seasonal succession, with non-motile cells dominating during the spring bloom and reaching their maximal biomass of $22.6 \mathrm{mg} \mathrm{C} \mathrm{m}^{-3}$ (IQR: 13.3-32.7 $\mathrm{mg} \mathrm{C} \mathrm{m}^{-3}$ ) in May, and motile cells taking over in summer with the biomass peak of $40.6 \mathrm{mg} \mathrm{C} \mathrm{m}^{-3}$ (IQR: 26.2-69.8 $\mathrm{mg} \mathrm{C} \mathrm{m}^{-3}$ ) in August (Fig. 2). The copepod community biomass in the English Channel is dominated by Calanus helgolandicus through most of the year, with Pseudocalanus elongatus and Paracalanus parvus increasing their biomass contribution over spring and autumn, respectively (Fig. $2 \mathrm{a}, \mathrm{b})$. The observed inter-annual variability in the dominant species mainly relates to the shifts in phenology of the development period and the maximum biomass reached (Fig. 2b). The large inter-annual variability is captured by the variance index $\left(c_{\mathrm{v}}\right)$ ranging between 1.17 and 1.35 for the dominant species.

Grouping copepod species into their corresponding feeding strategies reveals more robust patterns, with relatively lower $c_{\mathrm{v}}$ for each feeding group (0.90 for ambush and for 0.92 feeding-current feeders) when compared to the values obtained for individual species (Fig. 2c). Zooplankton biomass is strongly dominated by feeding-current feeders that reach the highest biomass of $13 \mathrm{mg} \mathrm{C} \mathrm{m}{ }^{-3}$ (IQR: 9.7$21.2 \mathrm{mg} \mathrm{C} \mathrm{m}^{-3}$ ) in the late spring (Fig. 2c,d), following the spring bloom (Fig. 2e). Seasonal distribution reveals that ambush feeders reach their highest biomass in spring (April) and autumn (October), with the maximum biomass of $2.1 \mathrm{mg} \mathrm{C} \mathrm{m}^{-3}$ (IQR: $1.8-2.4 \mathrm{mg} \mathrm{C} \mathrm{m}^{-3}$ ) following the latesummer bloom of their motile prey at $10 \mathrm{~m}$ depth (Fig. 2d,e). The two biomass peaks are controlled by a different

Fig. 2. Plankton community at the L4 station, English Channel: (a) seasonal contribution of different copepod species to total copepod biomass, (b) seasonal variability of the four most dominant copepod species (first four species listed in the legend), (c) biomass and (d) seasonal biomass distribution $(D)$ of all feeding-current feeders and ambush feeders (marked with * in the legend), (e) $D$ of their corresponding prey: non-motile and motile cells sampled at $10 \mathrm{~m}$ depth. Shaded areas denote the inter-quartile range (IQR; median $\pm 25 \%$ ). The mean annual variability is measured by variance index, $c_{v}=\mathrm{IQR} /$ median. Bars indicate the annual mean biomass $\left(\mathrm{mg} \mathrm{C} \mathrm{m}^{-3}\right)$ for corresponding groups. 

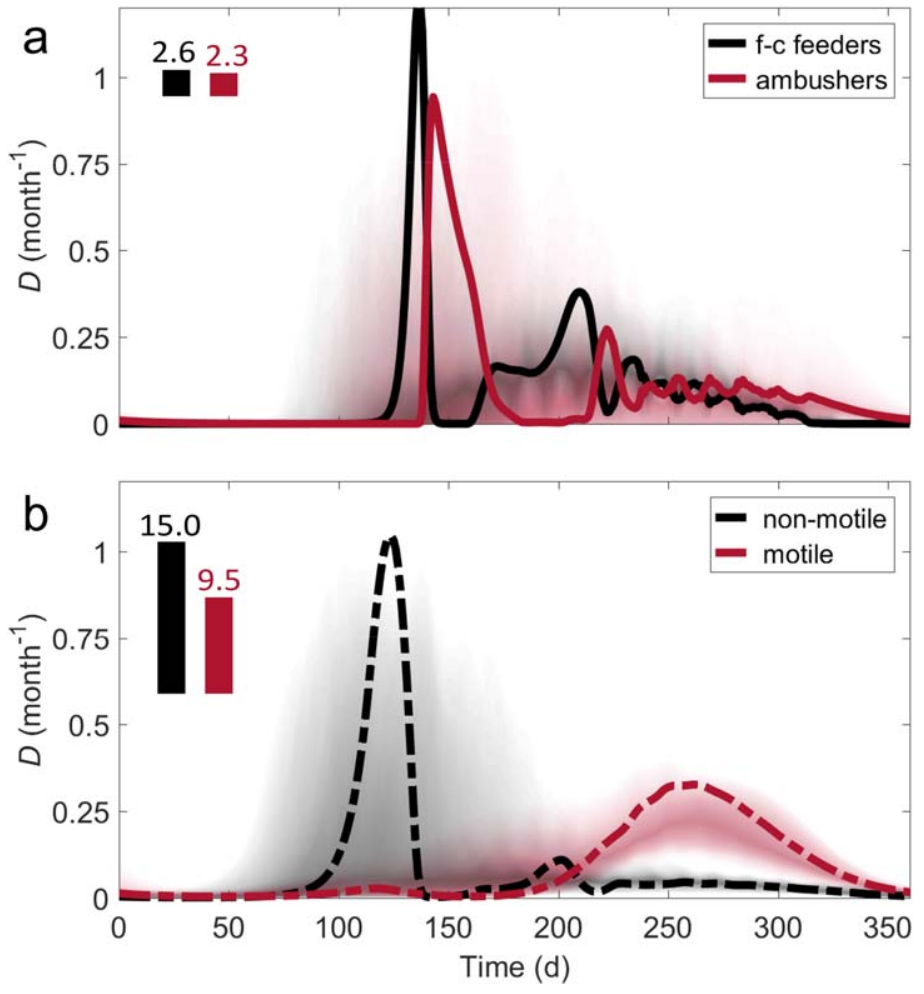

Fig. 3. Seasonal biomass distribution $(D)$ of vertically averaged (a) zooplankton and (b) protist plankton biomass, generated by the biological model. Bars indicate the annual mean biomass $\left(\mathrm{mg} \mathrm{C} \mathrm{m}^{-3}\right)$ for corresponding groups. For comparison with trait distribution in the English Channel, illustrated in Fig. 2d,e. Shaded area represents 95\% confidence intervals of the outcome of Monte Carlo simulations conducted with modification of all considered parameters simultaneously.

ambusher, with Oithona spp. driving the spring biomass and Corycaeus spp. thriving in autumn.

\section{Numerical model}

The water column integrated biomass of zooplankton groups reveals a seasonal succession of optimal feeding and motility traits (Fig. 3). The model qualitatively reproduces the seasonal succession of prey types and, hence, the protist motility traits in the English Channel (Fig. 3b). Similarly to observations, bloom of non-motile prey is initiated in March (days 61-90 of model simulation), reaching its peak biomass of $190.4 \mathrm{mg} \mathrm{C} \mathrm{m}^{-3}$ in May (days 121-150). Motile prey thrive in the summer with the highest biomass of $37.9 \mathrm{mg} \mathrm{C}$ $\mathrm{m}^{-3}$ reached in September (days 241-270), a month later than observed at the L4 station. Despite the overestimation of the magnitude of the spring bloom, the annual mean biomass of each group remains within the right order of magnitude as observed (see Fig. 2).

Feeding-current feeders thrive during the spring bloom of non-motile prey, but the strong grazing pressure drives rapid prey depletion. During the subsequent period of short-term food shortage, zooplankton switch to ambush feeding in order to reduce the risk of predation, which allows for prey recovery. Ambush feeding gains an advantage during summer by the blooming of motile prey (Fig. 3a). The simulations do not fully capture the timing of the early spring increase in the biomass of ambush feeders at the L4 station.

The numerical simulations reveal the vertical structuring of optimal feeding traits that is controlled by the interplay between the prey availability and the physical environment (Fig. 4). The spring bloom of non-motile cells favors growth of feeding-current feeders and the excess concentration of non-motile prey results in negligible effect of turbulence on selecting the optimal feeding mode. Later in the year, the role of turbulence becomes important for the vertical structuring of the zooplankton community. In late summer, feeding-current feeders occupy more stable depths, while ambush feeders benefit from enhanced prey encounter rates in the more turbulent parts of the water column. Environmentally driven selection for feeding-current feeders at middepths favors rapid growth of motile prey at the thermocline, and reinforces the seasonal succession of prey types. Intermittent changes in the optimal feeding strategy at middepths are driven by the spring-neap tidal cycle, which enhances turbulence and periodically erodes the thermocline. During the winter starvation period, ambush feeding becomes optimal due to the reduced predation mortality and more efficient feeding under turbulent conditions.

In the modelled environment, coexistence of the motile and non-motile prey types is enabled by the adaptive grazing pressure. In the absence of grazers, non-motile protists outcompete the motile community. Model results are relatively robust and modification of the parameters does not qualitatively alter the predicted trait distribution. Parameters that determine the growth rates of protist prey have the strongest impact on the succession of motility and feeding traits. Relative fitness of motile prey has a strong effect on how pronounced the succession between feeding-current and ambush feeders is in the summer/autumn. In case of a lack of pronounced autumn bloom of motile prey, the switch of zooplankton community to ambush feeding strategy is not as evident and occurs as a response to low concentrations of non-motile prey to optimize the survival of zooplankton community. Here, we illustrate model sensitivity to the modification of the light affinity $\left(A_{I}\right)$ as it is one of the parameters that lead to the highest variability in the biomass of plankton types (Fig. 5). More information on the model sensitivity to parameter choices is provided in the Supporting Information S2.

\section{Discussion}

We have used a trait-based approach to analyse and explain the seasonal succession in a pelagic community. Our description is based on the premise that trophic interactions can be reduced to a game between individuals with two 

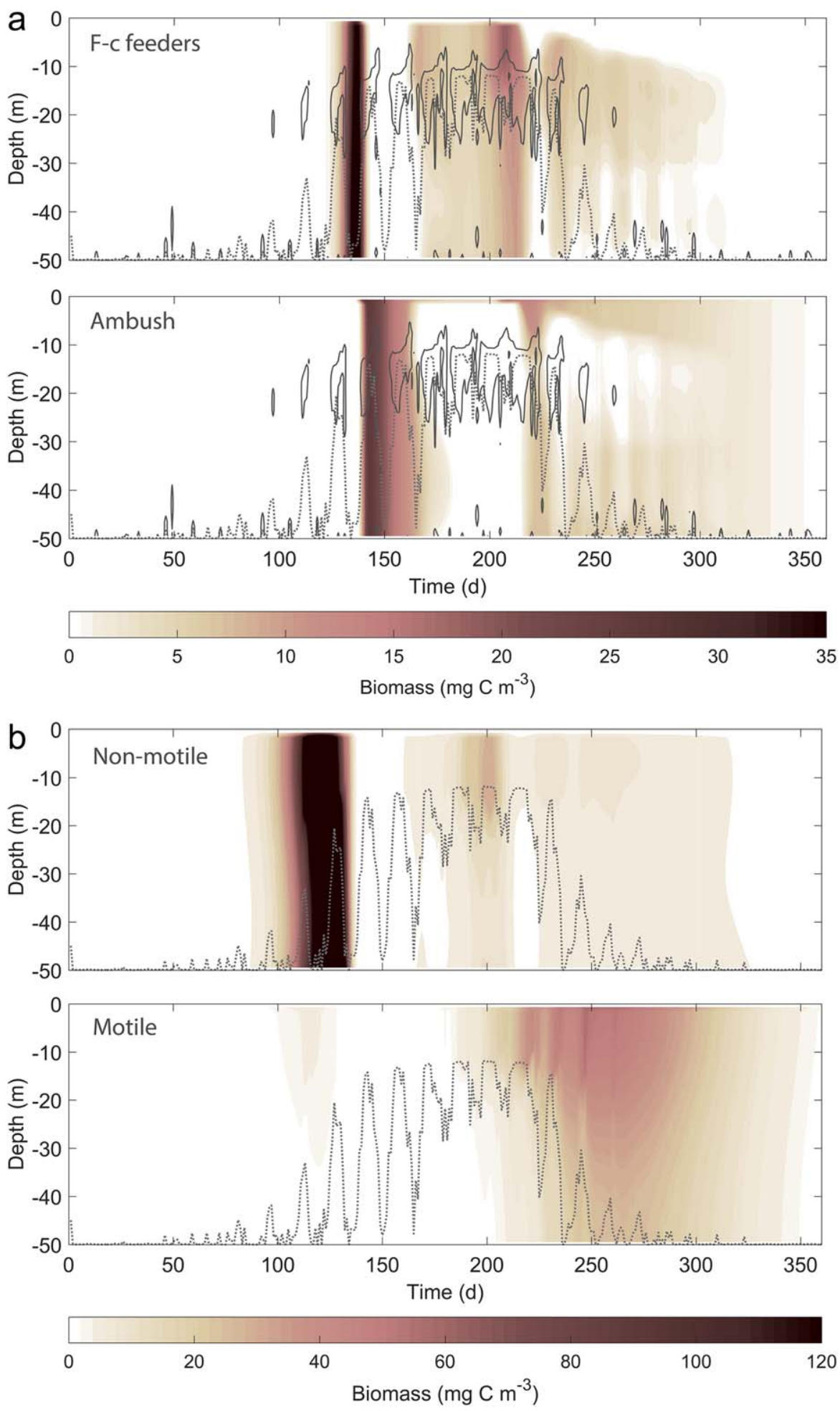

Fig. 4. Vertical biomass distribution of modelled: (a) zooplankton, feeding-current and ambush feeders, and (b) their corresponding prey, non-

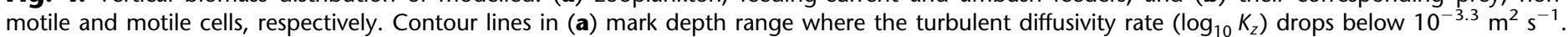
Dotted line in (a) and (b) indicates the mixed layer depth. 

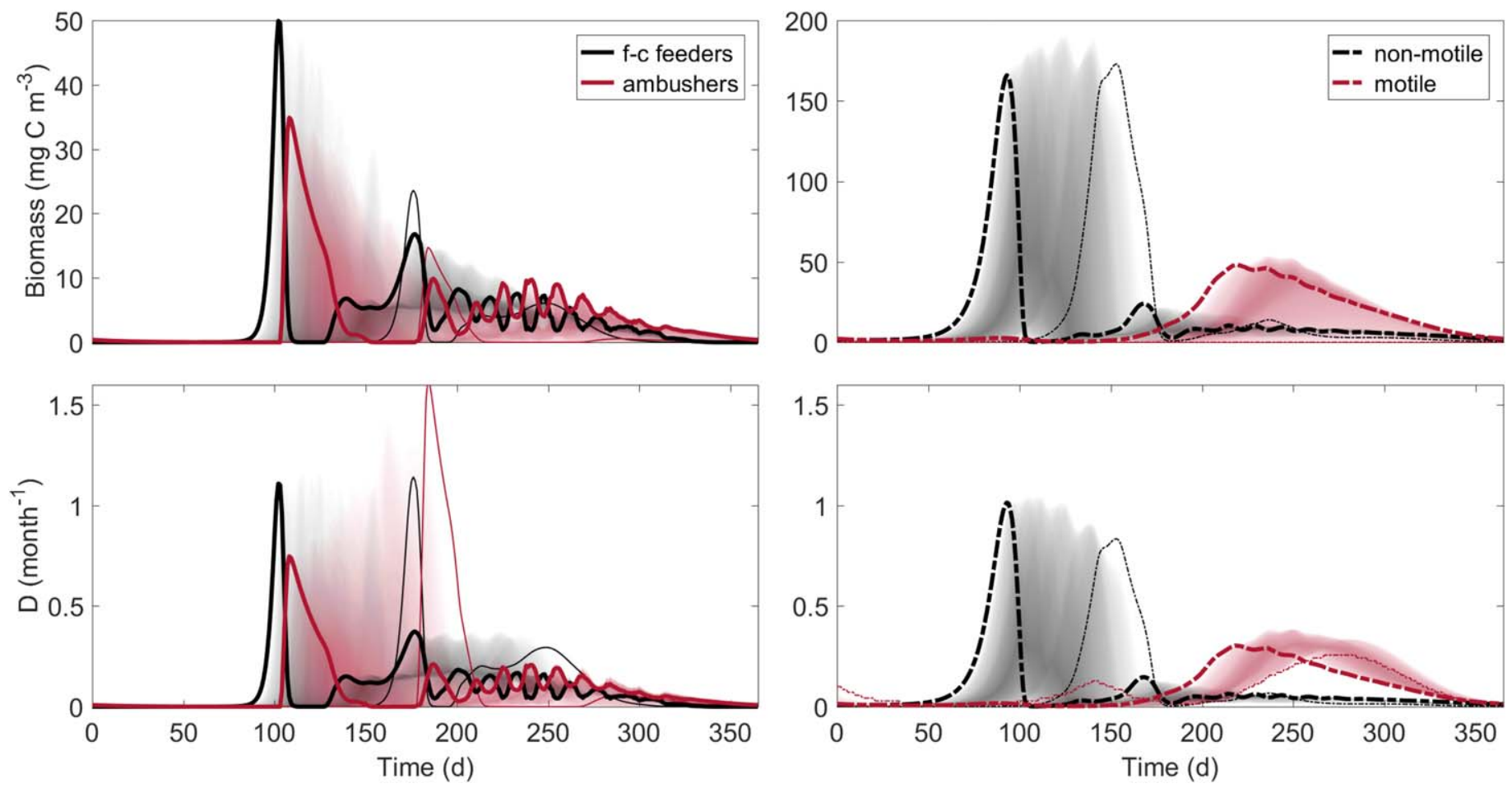

Fig. 5. Model sensitivity to changes in light affinity $\left(A_{l}\right)$ within the $\pm 30 \%$ margin. Top panels illustrate variability in water-column averaged biomass of zooplankton (left) and protist plankton (right). Corresponding seasonal distribution $(D)$ of traits is illustrated in the lower panels. Thinner lines indicate the model output with the parameter set to $70 \%$ of the base value indicated in Table $2\left(A_{l}=0.0665\left(\mathrm{~W} \mathrm{~m}^{-2}\right)^{-1} \mathrm{~d}^{-1}\right)$. Thicker lines show the model output with the parameter set to $130 \%$ of the base value $\left(A_{l}=0.1235\left(\mathrm{~W} \mathrm{~m}^{-2}\right)^{-1} \mathrm{~d}^{-1}\right)$. Shaded area illustrates $95 \%$ confidence intervals for all 1000 simulations with randomly assigned $A_{1}$.

traits: their trophic level and their degree of activity. In the modelled ecosystem, active (motile) protists experience a disadvantage through a lower affinity for nutrients, but benefit from the lack of sinking losses. In contrast, active mesozooplankters, such as feeding-current feeders, receive a higher foraging gain at the expense of an elevated predation risk with respect to their passive counterparts. Despite species on the same trophic level differing in many traits other than just activity level, our analysis of data from temperate seas demonstrates that the seasonal succession in the feeding mode is more robust than the seasonal succession among copepod species. The analysis spanning two trophic levels is an extension of previous trait-based descriptions of the seasonal succession of phytoplankton from data (Edwards et al. 2013) and models (Evans 1988) to include the role of zooplankton. Interestingly, the trade-offs between feeding and motility traits across trophic levels also allow for coexistence within the phytoplankton and zooplankton communities, a result that can be attributed to a killing-the-winner mechanism (Murdoch and Oaten 1975; Thingstad et al. 2005). Our model highlights the importance of mesozooplankton in shaping the seasonal succession of protists, and reveals how the seasonal trait succession can be explained as a trophic trait cascade.
The trait analysis reveals a robust succession pattern in these temperate seas, where the interannual variability in the trait succession is lower than the variability in the species succession. This robust seasonal succession stands in contrast to a species-based analysis (Reygondeau et al. 2015) that characterizes the succession in the English Channel as a non-repeatable pattern with strong interannual variability that has been attributed to a long-term environmental variability (Eloire et al. 2010; Reygondeau et al. 2015); however, no mechanistic underpinning of the effect of environmental fluctuations on species phenology has been demonstrated nor discussed. Here, we show how the variability in the physical environment affects the community selection for the optimal activity traits. Despite the interannual variation in dominant species, the seasonal succession of the community can therefore be described as a succession of activity traits.

The model successfully resolves the protist plankton succession with an initial bloom of non-motile cells followed by motile cells. In the model, motility comes at a cost of higher nutrient requirement and despite being weaker nutrient competitors, motile protists dominate the community in the summer. The modelled succession is therefore shaped purely by the seasonally varying predation pressure of zooplankton. 
Trophic level

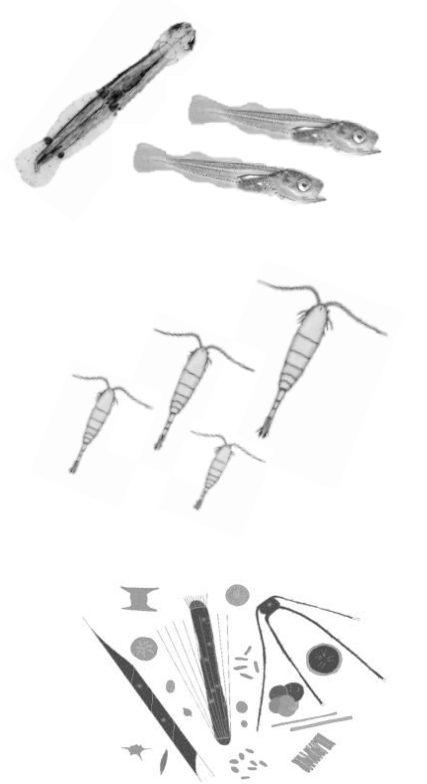

Spring

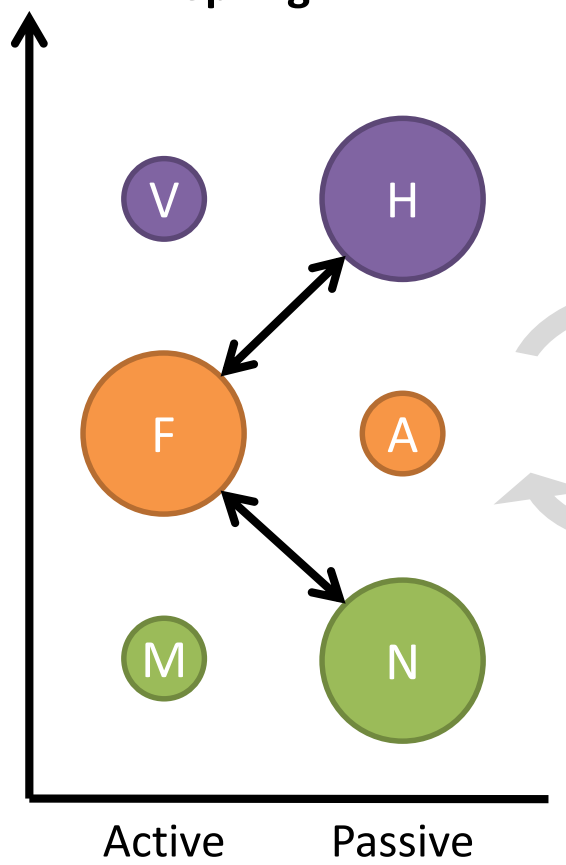

Summer

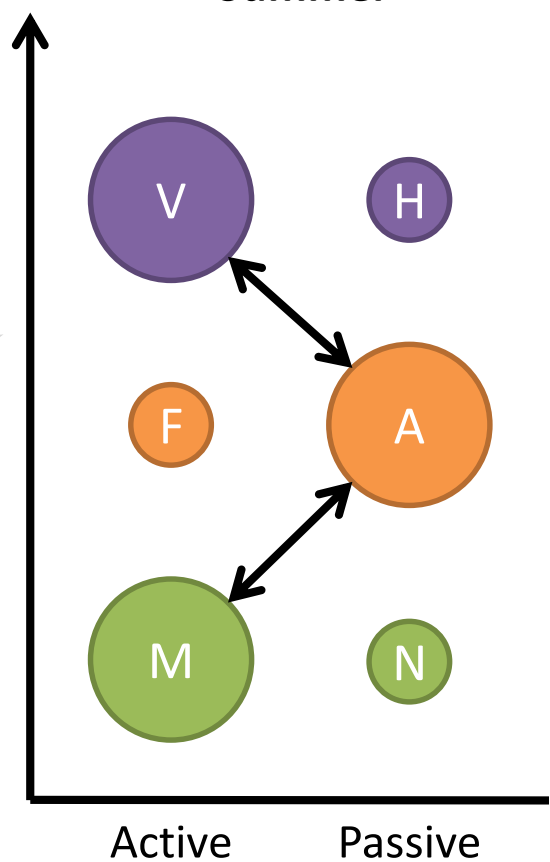

Fig. 6. Conceptual diagram illustrating seasonal selection for optimal traits and the trophic trait cascade. Traits are classified depending on the level of foraging activity, and are realized differently across distinct trophic levels: motile $(M)$ and non-motile ( $N$ ) protists, feeding-current feeding ( $F$ ) and ambush feeding (A) zooplankton, and classification based on sensory traits for visual $(\mathrm{V})$ and hydromechanical $(\mathrm{H})$ predators from a higher trophic level. The dominant community axis (black arrows) indicates the dominant energy pathway and alternates between spring and summer with changing light, nutrient and turbulence conditions. For more details see "Discussion" section.

In reality, vertical migration of motile cells enhances their survival ability in the stratified environment (Ross and Sharples 2007). Additionally, mixotrophy among some protist plankton, such as dinoflagellates, brings additional competitive benefit in the nutrient-deplete season (Bockstahler and Coats 1993; Stoecker 1999). These two mechanisms are important factors in controlling protist plankton seasonal succession and have not been implemented in the current model formulation. Hence, the cascading effect of zooplankton feeding presented here should be considered a contributing mechanism to the seasonal succession of motility traits or protist plankton. From a modelling perspective, the inclusion of trait diversity on the zooplankton trophic level is important in stabilizing coexistence of the two prey types, which is typically difficult to achieve with only one consumer type (Evans 1988). However, the most important feature of the model is that it reveals how not only the biomass distribution (Evans and Parslow 1985; Behrenfeld and Boss 2014), but also the trait succession is shaped by the topdown forcing from zooplankton.

A quantitative comparison between model and observations is not particularly robust. In part this is due to the incomplete observations of the succession of the plankton community and our simplified model view of nature. Three aspects of the modelled succession do not fit the observations:
1. The model predicts an approximately equal biomass of feeding-current feeders and ambush feeders, while the data show a dominance of feeding-current feeders throughout the season. This is partly a result of the simplified description of prey choice, where feeding-current feeders can only feed on non-motile prey. In reality, many feeding-current feeding copepods can capture both non-motile and motile prey (Doall et al. 2002; Kjellerup and Kiørboe 2012). This ability would further drive their biomass in the modelled environment. The model predicts relatively high biomass of ambushers at the surface. This over-representation could be likely explained by vertically uniform predation along the modelled water column, while in reality, visual predators (fish) exhibit increased activity in the well-lit surface waters. In addition, the model overlooks the complex carnivorous interactions (Paffenhöfer and Knowles 1980; Landry 1981; Turner et al. 1984; Nakamura and Turner 1997) that could further enhance the growth of larger active feeders.

2. The early spring increase in the biomass of ambush feeders, which in reality is largely formed by Oithona spp., is not captured by the model. This discrepancy suggests alternative food sources, such as sinking particles or phytoflagellates that are relatively abundant in the region throughout the year. In addition, Oithona spp. have been 
repeatedly observed to feed on diatoms especially during the periods of microzooplankton scarcity (Turner 1986; Castellani et al. 2005; Vogt et al. 2013), which is a likely behavioral or morphological trait that would favor their growth in early spring. The population of ambush feeders continues to grow for 2 months after the biomass peak of motile protists. This sustained growth could be driven by the alternative food source comprising, for example, of copepod nauplii.

3. There is a mismatch in the magnitude and the length of the spring bloom of non-motile cells observed in the English Channel and generated by the model. The development of a spring zooplankton biomass occurs as a rapid response to the bloom and in turn leads to the abrupt depletion of non-motile cells. In reality, copepod populations would be unable to respond so fast due to the ontogenetic growth from nauplii to adults, which process is not represented in the model. An additional shortcoming of the model is the lack of the interactions between nonmotile phytoplankton and microzooplankton, partially comprising the motile fraction of the community in the model. Microzooplankton has been previously reported to have an important effect on controlling the development of spring bloom of diatoms (Landry et al. 2000; Strom et al. 2001, 2007). The absence of these interactions does, at least partially, explain the rapid and "out-of-control" growth of non-motile cells during the spring bloom in the model. However, this aspect is too complex to be incorporated at the stage and would require a separate study.

The overarching goal of the model is not to quantitatively replicate the community dynamics in the English Channel, but to show that the proposed mechanism of trait interactions can be a potential driver of species seasonal succession. Apart from the obvious discrepancies with observations, the model captures the salient features of the trait succession, despite being a simplistic caricature of the complex trophic dynamics. Seasonal trait dynamics are discussed here in the context of plankton communities in the English Channel, however, the presented mechanism driving the trait succession could be equally valid for other regions experiencing seasonal stratification. The succession of motility traits is a well-documented feature across a range of aquatic provinces, such as coastal NW Adriatic (Bernardi Aubry et al. 2004), NE Atlantic (McQuatters-Gollop et al. 2007), or North Atlantic (Barton et al. 2013).

The strong links between traits at adjacent trophic levels lead us to suggest the existence of a trophic trait cascade through the entire pelagic food chain (Fig. 6). Herbivores and predatory organisms can optimize their fitness through investing in active foraging and benefiting from more efficient feeding, or reducing their predation mortality through application of a passive strategy. For higher trophic levels, a possible distinction stands between visual predators (V), such as fish larvae, and organisms that detect their prey using hydromechanical signals $(\mathrm{H})$, such as chaetognaths or passively feeding jellyfish. The dominant interaction is across traits, i.e., "passive" ambushing organisms only select active prey, while active predators target both active and passive prey. The trait selection can be driven bottom up via nutrient availability: for example, non-motile phytoplankton (N) bloom during nutrient-replete conditions in spring, and thus favor feeding-current feeding zooplankton (F) and their passive predators. This "dominant community axis" is reversed in summer, when nutrient-deplete conditions in the surface waters favor motile protists (M) and benefit the growth of ambush feeding zooplankton (A) and their visual predators. However, these patterns can be altered by additional forcing mechanisms modifying trait distribution at a particular trophic level. For example, strong turbulence favors ambushing zooplankton, and leads to an enhanced grazing pressure on motile prey. This mechanism provides a refuge for a non-motile protists and may reinforce a temporary shift in the dominant community axis. The classification of two trait types (active vs. passive) at each trophic level, and their predominantly alternating links, suggests an equilibrating effect on the trophic cascade of perturbations initiated within one trait type at a particular trophic level.

Quantifying the complex interactions within marine food webs is difficult, and understanding how these shape the continuously changing community structure of marine ecosystems is an even more daunting task. Trait-based ecology has been promoted as a conceptual framework that can cut through much of this complexity, and lend insight into mechanisms through which the properties of real ecosystems emerge (McGill et al. 2006; Litchman et al. 2007). While still far from a comprehensive explanation, this work suggests a path by which this may be achieved: traits can be viewed as descriptors of community assemblages and the dynamics of trait frequency within communities are subject to the everchanging consequences of trade-offs. In this work, we have been able to follow this line of analysis through the fortunate coincidence that highly idealized traits and their tradeoffs within plankton communities are also relatively robust descriptors of trophic arrangements in nature. The trophic trait cascade we identify here may well be an integrating feature in many seemingly complex ecosystems, with trait combinations mapping across trophic guilds.

\section{References}

Abrams, P. A., H. Matsuda, and Y. Harada. 1993. Evolutionarily unstable fitness maxima and stable fitness minima of continuous traits. Evol. Ecol. 7: 465-487. doi:10.1007/ BF01237642

Abrams, P., and H. Matsuda. 2004. Consequences of behavioral dynamics for the population dynamics of predatorprey systems with switching. Popul. Ecol. 46: 13-25. doi: 10.1007/s10144-003-0168-2 
Acevedo-Trejos, E., G. Brandt, J. Bruggeman, and A. Merico. 2015. Mechanisms shaping size structure and functional diversity of phytoplankton communities in the ocean. Sci. Rep. 5: 8918. doi:10.1038/srep08918 doi:10.1038/ srep08918

Barton, A. D., Z. V. Finkel, B. A. Ward, D. G. Johns, and M. J. Follows. 2013. On the roles of cell size and trophic strategy in North Atlantic diatom and dinoflagellate communities. Limnol. Oceanogr. 58: 254-266. doi:10.4319/ lo.2013.58.1.0254

Behrenfeld, M. J., and E. S. Boss. 2014. Resurrecting the ecological underpinnings of ocean plankton blooms. Ann. Rev. Mar. Sci. 6: 167-194. doi:10.1146/annurev-marine052913-021325

Benedetti, F., S. Gasparini, and S. D. Ayata. 2015. Identifying copepod functional groups from species functional traits. J. Plankton Res. 38: 159-166. doi:10.1093/plankt/fbv096

Berggreen, U., B. Hansen, and T. Kiørboe. 1988. Food size spectra, ingestion and growth of the copepod Acartia tonsa during development: Implications for determination of copepod production. Mar. Biol. 99: 341-352. doi: 10.1007/BF02112126

Bernardi Aubry, F., A. Berton, M. Bastianini, G. Socal, and F. Acri. 2004. Phytoplankton succession in a coastal area of the NW Adriatic, over a 10-year sampling period (1990-1999). Cont. Shelf Res. 24: 97-115. doi:10.1016/j.csr.2003.09.007

Bidigare, R., J. Marra, T. Dickey, R. Iturriaga, K. Baker, R. Smith, and H. Pak. 1990. Evidence for phytoplankton succession and chromatic adaptation in the Sargasso Sea during spring 1985. Mar. Ecol. Prog. Ser. 60: 113-122. doi: 10.3354/meps060113

Bockstahler, K., and D. Coats. 1993. Grazing of the mixotrophic dinoflagellate Gymnodinium sanguineum on ciliate populations of Chesapeake Bay. Mar. Biol. 116: 477-487. doi:10.1007/BF00350065

Bottrell, H., and D. Robins. 1984. Seasonal variations in length, dry weight, carbon and nitrogen of Calanus helgolandicus from the Celtic Sea. Mar. Ecol. Prog. Ser. 14: 259-268. doi:10.3354/meps014259

Burchard, H., K. Bolding, W. Kühn, A. Meister, T. Neumann, and L. Umlauf. 2006. Description of a flexible and extendable physical-biogeochemical model system for the water column. J. Mar. Syst. 61: 180-211. doi:10.1016/ j.jmarsys.2005.04.011

Castellani, C., X. Irigoien, R. P. Harris, and R. S. Lampitt. 2005. Feeding and egg production of Oithona similis in the North Atlantic. Mar. Ecol. Prog. Ser. 288: 173-182. doi: $10.3354 /$ meps 288173

Conway, D. V. P. 2012a. Identification of the copepodite developmental stages of twenty-six North Atlantic copepods. Marine Biological Association Occasional Publication No. 21.

Conway, D. V. P. 2012b. Marine Zooplankton of Southern Britain, Part 2: Arachnida, Pycnogonida, Cladocera,
Facetotecta, Cirripedia and Copepoda, p. 1-164. Marine Biological Association Occasional Publication No. 26.

Delichatsios, M. A., and R. F. Probstein. 1975. Coagulation in turbulent flow: Theory and experiment. J. Colloid Interface Sci. 51: 394-405. doi:10.1016/0021-9797(75)90135-6

Doall, M. H., J. R. Strickler, D. M. Fields, and J. Yen. 2002. Mapping the free-swimming attack volume of a planktonic copepod, Euchaeta rimana. Mar. Biol. 140: 871-879. doi:10.1007/s00227-001-0735-z

Edwards, K. F., M. K. Thomas, C. A. Klausmeier, and E. Litchman. 2012. Allometric scaling and taxonomic variation in nutrient utilization traits and maximum growth rate of phytoplankton. Limnol. Oceanogr. 57: 554-566. doi:10.4319/1o.2012.57.2.0554

Edwards, K. F., E. Litchman, and C. A. Klausmeier. 2013. Functional traits explain phytoplankton community structure and seasonal dynamics in a marine ecosystem. Ecol. Lett. 16: 56-63. doi:10.1111/ele.12012

Eiane, K., and M. D. Ohman. 2004. Stage-specific mortality of Calanus finmarchicus, Pseudocalanus elongatus and Oithona similis on Fladen Ground, North Sea, during a spring bloom. Mar. Ecol. Prog. Ser. 268: 183-193. doi: 10.3354/meps 268183

Eloire, D., P. J. Somerfield, D. V. P. Conway, C. HalsbandLenk, R. Harris, and D. Bonnet. 2010. Temporal variability and community composition of zooplankton at station L4 in the Western Channel: 20 years of sampling. J. Plankton Res. 32: 657-679. doi:10.1093/plankt/fbq009

Eppley, R. W. 1972. Temperature and phytoplankton growth in the sea. Fish. Bull. 70: 1063-1085.

Evans, G. T. 1988. A framework for discussing seasonal succession and coexistence of phytoplankton species. Limnol. Oceanogr. 33: 1027-1036. doi:10.4319/lo.1988.33.5.1027

Evans, G. T., and J. S. Parslow. 1985. A model of annual plankton cycles. Deep-Sea Res. Part B Oceanogr. Lit. Rev. 32: 759. doi:10.1080/01965581.1985.10749478

Falkowski, P. G., and T. G. Owens. 1980. Light- shade adaptation. Plant Physiol. 66: 592-595. doi:10.1104/ pp.66.4.592

Follows, M. J., S. Dutkiewicz, S. Grant, and S. W. Chisholm. 2007. Emergent biogeography of microbial communities in a model ocean. Science 315: 1843-1846. doi:10.1126/ science. 1138544

Go, Y. B., B. C. Oh, and M. Terazaki. 1998. Feeding behavior of the poecilostomatoid copepods Oncaea spp. on chaetognaths. J. Mar. Syst. 15: 475-482. doi:10.1016/S09247963(97)00038-9

Hickman, A., S. Dutkiewicz, R. Williams, and M. Follows. 2010. Modelling the effects of chromatic adaptation on phytoplankton community structure in the oligotrophic ocean. Mar. Ecol. Prog. Ser. 406: 1-17. doi:10.3354/ meps08588

Hopcroft, R. R., J. C. Roff, and D. Lombard. 1998. Production of tropical copepods in Kingston Harbour, Jamaica: The 
importance of small species. Mar. Biol. 130: 593-604. doi: $10.1007 / \mathrm{s} 002270050281$

Jakobsen, H. H. 2002. Escape of protists in predator generated feeding currents. Aquat. Microb. Ecol. 26: 271-281. doi:10.3354/ame026271

Kiørboe, T. 2008a. Optimal swimming strategies in matesearching pelagic copepods. Oecologia 155: 179-192. doi: 10.1007/s00442-007-0893-x

Kiørboe, T. 2008b. A mechanistic approach to plankton ecology. Princeton Univ. Press.

Kiørboe, T. 2011. How zooplankton feed: Mechanisms, traits and trade-offs. Biol. Rev. 86: 311-339. doi:10.1111/j.1469185X.2010.00148.X

Kiørboe, T., E. Saiz, and M. Viitasalo. 1996. Prey switching behaviour in the planktonic copepod Acartia tonsa. Mar. Ecol. Prog. Ser. 143: 65-75. doi:10.3354/meps143065

Kjellerup, S., and T. Kiørboe. 2012. Prey detection in a cruising copepod. Biol. Lett. 8: 438-441. doi:10.1098/ rsbl.2011.1073

Landry, M. R. 1981. Switching between herbivory and carnivory by the planktonic marine copepod Calanus pacificus. Mar. Biol. 65: 77-82. doi:10.1007/BF00397070

Landry, M., J. Constantinou, M. Latasa, S. Brown, R. Bidigare, and M. Ondrusek. 2000. Biological response to iron fertilization in the eastern equatorial Pacific (IronEx II). III. Dynamics of phytoplankton growth and microzooplankton grazing. Mar. Ecol. Prog. Ser. 201: 57-72. doi: 10.3354/meps201057

Litchman, E., C. A. Klausmeier, O. M. Schofield, and P. G. Falkowski. 2007. The role of functional traits and tradeoffs in structuring phytoplankton communities: Scaling from cellular to ecosystem level. Ecol. Lett. 10: 11701181. doi:10.1111/j.1461-0248.2007.01117.x

Litchman, E., and C. A. Klausmeier. 2008. Trait-based community ecology of phytoplankton. Annu. Rev. Ecol. Evol. Syst. 39: 615-639. doi:10.1146/annurev.ecolsys.39.110707.173549

Litchman, E., P. de Tezanos Pinto, C. A. Klausmeier, M. K. Thomas, and K. Yoshiyama. 2010. Linking traits to species diversity and community structure in phytoplankton. Hydrobiologia 653: 15-28. doi:10.1007/s10750-0100341-5

Litchman, E., M. D. Ohman, and T. Kiørboe. 2013. Traitbased approaches to zooplankton communities. J. Plankton Res. 35: 473-484. doi:10.1093/plankt/fbt019

Mariani, P., and A. W. Visser. 2010. Optimization and emergence in marine ecosystem models. Prog. Oceanogr. 84: 89-92. doi:10.1016/j.pocean.2009.09.010

Mariani, P., K. H. Andersen, A. W. Visser, A. D. Barton, and T. Kiørboe. 2013. Control of plankton seasonal succession by adaptive grazing. Limnol. Oceanogr. 58: 173-184. doi: 10.4319/lo.2013.58.1.0173

McGill, B. J., B. J. Enquist, E. Weiher, and M. Westoby. 2006. Rebuilding community ecology from functional traits. Trends Ecol. Evol. 21: 178-185. doi:10.1016/j.tree.2006.02.002
McQuatters-Gollop, A., D. E. Raitsos, M. Edwards, and M. J. Attrill. 2007. Spatial patterns of diatom and dinoflagellate seasonal cycles in the NE Atlantic Ocean. Mar. Ecol. Prog. Ser. 339: 301-306. doi:10.3354/meps339301

Menden-Deuer, S., and E. J. Lessard. 2000. Carbon to volume relationships for dinoflagellates, diatoms, and other protist plankton. Limnol. Oceanogr. 45: 569-579. doi: 10.4319/lo.2000.45.3.0569

Monteiro, F. M., M. J. Follows, and S. Dutkiewicz. 2010. Distribution of diverse nitrogen fixers in the global ocean. Global Biogeochem. Cycles 24: GB3017. doi:10.1029/2009GB003731

Murdoch, W. W., and A. Oaten. 1975. Predation and population stability. Adv. Ecol. Res. 9: 1-131. doi:10.1016/S00652504(08)60288-3

Nakamura, Y., and J. T. Turner. 1997. Predation and respiration by the small cyclopoid copepod Oithona similisr: How important is feeding on ciliates and heterotrophic flagellates? J. Plankton Res. 19: 1275-1288. doi:10.1093/ plankt/19.9.1275

Paffenhöfer, G. A., and S. C. Knowles. 1980. Omnivorousness in marine planktonic copepods. J. Plankton Res. 2: 355365. doi:10.1093/plankt/2.4.355

Redfield, A. C. 1958. The biological control of chemical factors in the environment. Am. Sci. 46: 205-221.

Reygondeau, G., J. C. Molinero, S. Coombs, B. R. MacKenzie, and D. Bonnet. 2015. Progressive changes in the Western English Channel foster a reorganization in the plankton food web. Prog. Oceanogr. 137: 524-532. doi:10.1016/ j.pocean.2015.04.025

Richardson, L. F. 1926. Atmospheric diffusion shown on a distance-neighbour graph. Proc. R. Soc. A 110: 709-737. doi:10.1098/rspa.1926.0043

Rose, M. 1933. Copépodes pélagiques. Faune de France, vol. 26. Lachevalier, Paris.

Ross, O. N., and J. Sharples. 2007. Phytoplankton motility and the competition for nutrients in the thermocline. Mar. Ecol. Prog. Ser. 347: 21-38. doi:10.3354/meps06999

Saiz, E., and T. Kiørboe. 1995. Predatory and suspension feeding of the copepod Acartia tonsa in turbulent environments. Mar. Ecol. Prog. Ser. 122: 147-158. doi: 10.3354/meps 122147

Seuront, L., J. S. Hwang, L. C. Tseng, F. G. Schmitt, S. Souissi, and C. K. Wong. 2004. Individual variability in the swimming behavior of the sub-tropical copepod Oncaea venusta (Copepoda: Poecilostomatoida). Mar. Ecol. Prog. Ser. 283: 199-217. doi:10.3354/meps283199

Smyth, T. J., and others. 2010. A broad spatio-temporal view of the Western English Channel observatory. J. Plankton Res. 32: 585-601. doi:10.1093/plankt/fbp128

Stoecker, D. K. 1999. Mixotrophy among dinoflagellates. J. Eukaryot. Microbiol. 46: 397-401. doi:10.1111/j.15507408.1999.tb04619.x

Strom, S. L., M. A. Brainard, J. L. Holmes, and M. B. Olson. 2001. Phytoplankton blooms are strongly impacted by 
microzooplankton grazing in coastal North Pacific waters. Mar. Biol. 138: 355-368. doi:10.1007/s002270000461

Strom, S. L., E. L. Macri, and M. B. Olson. 2007. Microzooplankton grazing in the coastal Gulf of Alaska: Variations in top-down control of phytoplankton. Limnol. Oceanogr. 52: 1480-1494. doi:10.4319/lo.2007.52.4.1480

Thingstad, T. F., L. Øvreås, J. K. Egge, T. Løvdal, and M. Heldal. 2005. Use of non-limiting substrates to increase size; a generic strategy to simultaneously optimize uptake and minimize predation in pelagic osmotrophs? Ecol. Lett. 8: 675-682. doi:10.1111/j.1461-0248.2005.00768.x

Thomas, M. K., C. T. Kremer, C. A. Klausmeier, and E. Litchman. 2012. A global pattern of thermal adaptation in marine phytoplankton. Science 338: 1085-1089. doi: 10.1126/science. 1224836

Tilman, D. 1982. Resource competition and community structure. Princeton Univ. Press.

Turner, J. T., P. Tester, and W. Conley. 1984. Zooplankton feeding ecology: Predation by the marine cyclopoid copepod Corycaeus amazonicus F. Dahl upon natural prey. J. Exp. Mar. Biol. Ecol. 84: 191-202. doi:10.1016/00220981(84)90212-0

Turner, T. 1986. Zooplankton feeding ecology: Contents of fecal pellets of the cyclopoid copepods Oncaea venusta, Corycaeus amazonicus, Oithona plumifera, and O. simplex from the Northern Gulf of Mexico. Mar. Ecol. 7: 289-302. doi:10.1111/j.1439-0485.1986.tb00165.X
Vogt, R. A., T. R. Ignoffo, L. J. Sullivan, J. Herndon, J. H. Stillman, and W. J. Kimmerer. 2013. Feeding capabilities and limitations in the nauplii of two pelagic estuarine copepods, Pseudodiaptomus marinus and Oithona davisae. Limnol. Oceanogr. 58: 2145-2157. doi:10.4319/ lo.2013.58.6.2145

Widdicombe, C. E., D. Eloire, D. Harbour, R. P. Harris, and P. J. Somerfield. 2010. Long-term phytoplankton community dynamics in the Western English Channel. J. Plankton Res. 32: 643-655. doi:10.1093/plankt/fbp127

\section{Acknowledgments}

We thank Thomas Kiørboe for insightful discussions and advice. This work was supported by the Centre for Ocean Life, a VKR Centre of excellence funded by the Villum Foundation. The L4 plankton time-series data was provided by the Western Channel Observatory and British Oceanographic Data Centre, supported by the Natural Environment Research Council.

\section{Conflict of Interest}

None declared.
Submitted 14 July 2016

Revised 08 November 2016

Accepted 15 November 2016 